\title{
Leishmanicidal activities of the extract from Blepharocalyx salicifolius (Kunth) O. Berg, Myrtaceae
}

\author{
Ezequias Pessoa de Siqueira, ${ }^{* 1}$ Elaine Maria de Souza-Fagundes, ${ }^{2}$ Marcos Eduardo Guerra \\ Sobral, ${ }^{3}$ Tânia Maria de Almeida Alves, ${ }^{1}$ Ana Rabello, ${ }^{1}$ Carlos Leomar Zani ${ }^{1}$
}

\author{
${ }^{1}$ Laboratório de Química de Produtos Naturais, Centro de Pesquisas Rene Rachou, Fundação Oswaldo Cruz, Av. \\ Augusto de Lima, 1715, 30190002 Belo Horizonte-MG, Brazil, \\ ${ }^{2}$ Departamento de Biofísica e Fisiologia, Instituto de Ciências Biológicas, Universidade Federal de Minas Gerais, Av. \\ Antônio Carlos, 6627, 31270901 Belo Horizonte-MG, Brazil, \\ ${ }^{3}$ Departamento de Botânica, Instituto de Ciêncais Biológicas, Universidade Federal de Minas Gerais, Av. Antônio \\ Carlos, 6627, Caixa Postal 486, 31270-901 Belo Horizonte-MG, Brazil.
}

\begin{abstract}
RESUMO: “Atividade leishmanicida do extrato de Blepharocalyx salicifolius (Kunth) O. Berg, Myrtaceae”. O extrato etanólico bruto de Blepharocalyx salicifolius (Kunth) O. Berg, Myrtaceae, foi fracionado por meio de Cromatografia de Permeação em Gel, utilizando-se Sephadex ${ }^{\mathrm{TM}}$ LH-20. Dezesseis frações foram obtidas e foram submetidas ao ensaio de citotoxicidade in vitro contra células amastigotas de Leishmania (Leishmania) amazonensis. Verificou-se atividade citocida contra células amastigotas de Leishmania (L.) amazonensis em oito frações, a uma concentração de 19 a $29 \mu \mathrm{g} . \mathrm{mL}^{-1}$. Duas destas frações apresentaram baixa toxicidade para células mononucleares de sangue periférico humano, com grande potencial de isolamento de substâncias leishmanicidas mais seletivas.
\end{abstract}

Unitermos: Blepharocalyx salicifolius, Myrtaceae, Leishmania (Leishmania) amazonensis, cromatografia de permeação em gel, citotoxicidade.

\begin{abstract}
Crude ethanolic extracts from Blepharocalyx salicifolius (Kunth) O. Berg, Myrtaceae, was fractioned by Gel Permeation Chromatography, using Sephadex ${ }^{\mathrm{TM}}$ LH-20 gel. Sixteen fractions were obtained and were supplied to cytotoxicity in vitro assay against Leishmania (L.) amazonensis amastigota cells. It was observed eight cytotoxic fractions against Leishmania (L.) amazonensis amastigota cells at range of 19 to $29 \mu \mathrm{g} \cdot \mathrm{mL}^{-1}$. Two of them were not citotoxic against human peripheral blood mononuclear cell, with a great potential to isolation of more selective leishmanicidal substances.
\end{abstract}

Keywords: Blepharocalyx salicifolius, Myrtaceae, Leishmania (Leishmania) amazonensis, gel permeation chromatography, citotoxicity.

\section{INTRODUCTION}

Leishmaniasis is caused by parasitic protozoa of the genus Leishmania. Humans are infected via the bite of phlebotomine sandflies, which breed in forest areas, caves, or the burrows of small rodents. There are four main types of the disease: cutaneous, diffuse cutaneous, mucocutaneous and visceral. If left untreated, the disease can have a fatality rate as high as $100 \%$ within two years. It is an endemic disease in 88 countries, mainly developing countries (Afghanistan, Bangladesh, Bolivia, Brazil, India, Iran, Nepal, Peru, Saudi Arabia, Sudan, Syria). Brazil has an important epidemiologic status, where all kinds of leishmaniasis were reported. (WHO, 2003).

The usual therapies against leishmaniasis do not have high efficacy, are extremely toxic and the pharmaceutical industries do not have economic refund to research new drugs in developing countries. According to Pecoul et al. (1999) only thirteen new drugs against tropical diseases were commercialized since 1975 to 1997 in a total of 1233 new drugs. Due to geographic broad dispersion, mainly in poorest countries, a great number of patients and the lack of therapeutic arsenal, the development of new drugs that can be used against leishmaniasis are very important.

In this work, preliminary studies were carried out to investigate the antiparasitic activity of fractions from Blepharocalyx salicifolius (Kunth) O. Berg, Myrtaceae, against amastigotes of Leishmania (L.) amazonensis and the toxicity against normal peripheral blood mononuclear 
cells (PBMC).

\section{MATERIAL AND METHODS}

\section{Collection of the vegetal material and crude extract production}

Leaves of Blepharocalyx salicifolius (Kunth) $\mathrm{O}$. Berg, Myrtaceae, specie were collected at Parque Estadual do Rio Preto, Minas Gerais State, Brazil, in November 2006. Exsiccates of the species were committed at UFMG Herbarium. The leaves were dried using an oven at $35^{\circ} \mathrm{C}$ for two weeks. The leaves were grounded and conditioned in ethanol (analytical grade) for two months. The crude extract was obtained after filtration and evaporation of the solvent.

\section{Gel permeation chromatography system}

The Gel permeation chromatography system was constituted by a glass column of $50 \mathrm{~mm}$ diameter and $250 \mathrm{~mm}$ length coupled in series to the two other similar columns of $50 \mathrm{~mm}$ diameter and $480 \mathrm{~mm}$ length, filled with Sephadex ${ }^{\mathrm{TM}}$ LH-20 (GE Healthcare, USA.) gel. The system was pumped by means of a P-500 (Pharmacia, USA.) pump. It was used distilled ethanol as mobile phase pumped at $2 \mathrm{~mL} \cdot \mathrm{min}^{-1}$. The fractions were collected by SF 2120 (Advantec, JP) collector, it was used 120 tubes of 22 $\mathrm{mL}$.

\section{Thin layer chromatography}

Thin layer chromatography was developed using $20 \times 20 \mathrm{~cm}^{2} \mathrm{HF}_{254}$ (Merck) plates. Ethyl acetate, hexane, dichloromethane and methanol were used as solvents. The chromatograms were revealed by means of vanillin or NP/ PEG.

Procedure for determinations of hydrodynamics parameters of the gel permeation chromatography system

Void volume $\left(\mathrm{V}_{0}\right)$ and inclusion volume $\left(\mathrm{V}_{\mathrm{i}}\right)$ were determined using an ethanolic solution of polyvidone $20 \mathrm{kDa}$ (Sigma-aldrich) at $1 \mathrm{mg} / \mathrm{mL}$ and benzophenone (Merck) at $1 \mathrm{mg} \cdot \mathrm{mL}^{-1}$, respectively. Twenty $\mathrm{ml}$ of the mixture $(1: 1 \mathrm{v} / \mathrm{v})$ were pumped at $5 \mathrm{~mL} \cdot \mathrm{min}^{-1}$, using ethanol as solvent. The column systems were coupled to UV/VIS detector SPD 10-A (Shimadzu, JP). The data were analyzed using Class LC-10 software (Shimadzu, JP).

\section{Chromatography of the Blepharocalyx salicifolius raw extract}

Twenty $\mathrm{ml}$ of the ethanolic solution at $187 \mathrm{mg} \cdot \mathrm{mL}^{-1}$ were separated by gel permeations chromatography, performing $3.74 \mathrm{~g}$ of raw extract. Ethanol was used as mobile phase at $2.0 \mathrm{~mL} \cdot \mathrm{min}^{-1}$. The fractions were analyzed and grouped according to thin layer chromatography chemical profile.

\section{Assays using amastigotes of Leishmania (L.) amazonensis}

Promastigotes of Leishmania (L.) amazonensis (strain IFLA/BR/196/PH-8) were obtained from lesions of infected hamsters. The parasites were grown at $26^{\circ} \mathrm{C}$ in $\mathrm{pH}$ 7.2 Schneider's medium, and then stimulated to differentiate into the amastigote forms by rising the temperature ( 32 ${ }^{\circ} \mathrm{C}$ ), and lowering the $\mathrm{pH}(6.0)$ of the Schneider's medium. After $7 \mathrm{~d}$ under these conditions, $90 \%$ of the promastigotes were transformed into amastigote-like forms, verified by means of microscope, and then used in the bioassays. Amastigote density was adjusted to $1 \times 10^{8}$ parasites per $\mathrm{mL}$, and $90 \mu \mathrm{L}$ added to each well of 96-well plates. Solutions at $200 \mu \mathrm{g} \cdot \mathrm{mL}^{-1}$ in DMSO (1\% in water) were performed for each fraction and then ten microliters of the solution were added to each well of 96 -well plates. The plates were incubated at $32{ }^{\circ} \mathrm{C}$ for $72 \mathrm{~h}$, and then the cells viability was determined using the MTT (methyl thiazolyl tetrazolium) assay (Teixeira et al., 2002). The results are expressed as percent inhibition in relation to the controls without drug. Amphotericin B at $0.2 \mu \mathrm{g} \cdot \mathrm{mL}^{-1}$ (Fungison $^{\circledR}$ Bristol-Myers Squibb B, Brazil) was used as a positive drug control. All assays were performed in triplicate.

\section{Proliferation assay with human Peripheral Mononuclear Blood Cells (PBMC)}

Peripheral blood mononuclear cells (PBMCs) were prepared using the protocol previously described by Gazzinelli et al. (1983). PBMCs were obtained from healthy adult volunteers of both sexes by centrifugation of heparinized venous blood over a Ficoll/Hypaque cushion. Mononuclear cells were collected from the interphase after Ficoll separation and washed three times in RPMI1640 before further processing. The cell suspensions were adjusted to $1.5 \times 10^{6}$ cells. $\mathrm{mL}^{-1}$. All cultures were carried out in RPMI-1640 medium, supplemented with $5 \%(\mathrm{v} / \mathrm{v})$ heat-inactivated, pooled $\mathrm{AB}$ sera and $2 \mathrm{mM}$ L-glutamine. An antibiotic/antimicotic solution containing $1000 \mathrm{U}$ penicillin. $\mathrm{mL}^{-1}, 1000 \mathrm{mg}$ streptomycin. $\mathrm{mL}^{-1}$ and $25 \mathrm{mg}$ fungisone. $\mathrm{mL}^{-1}$ was added to control fungal and bacterial contamination (complete medium). The cell proliferation and viability were determined by the MTT assay (Jiang \& Xu, 2003). Briefly, the cells are incubated with the extracts fractions at $20 \mu \mathrm{g} . \mathrm{mL}^{-1}$ and controls stimulated with $2.5 \mu$ g. $\mathrm{mL}^{-1}$ Phytohemagglutinin (PHA, or phytohemagglutinin). After $72 \mathrm{~h}, 20 \mu \mathrm{L}$ of MTT solution (5 mg. $\mathrm{mL}^{-1}$ in RPMI filtered through $0.2 \mu \mathrm{m}$ pore size filter) were added to the plates and incubated at $37{ }^{\circ} \mathrm{C}$ for $4 \mathrm{~h}$. The supernatant was carefully removed and 200 
$\mu \mathrm{L}$ of $\mathrm{HCl} 0.04 \mathrm{~N}$ in isopropanol was added to dissolve the formazan crystals. The absorbance was measured at $590 \mathrm{~nm}$ with a microplate reader (VersaMax Tunable, Molecular Devices).

\section{RESULTS}

\section{Chromatographic system}

The hydrodynamics parameters $\mathrm{V}_{0}$ and $\mathrm{V}_{\mathrm{i}}$ were obtained as $630 \mathrm{~mL}$ and $2125 \mathrm{~mL}$, respectively, as showed at Figure 1. None specie was detected before $V_{0}$. Between $\mathrm{V}_{0}$ and $\mathrm{V}_{\mathrm{i}}$ the separations occurred mainly by molecular exclusion. After $\mathrm{V}_{\mathrm{i}}$, adsorption was the main process of separation. These statements could be observed by means of the chemical profile obtained by thin layer chromatography. Data not showed.

As we know that before $\mathrm{V}_{0}$ none of the species can be detected (hydrodynamics parameters), the collections of the samples started after elution of $600 \mathrm{~mL}$ of ethanol. It was collected 190 fractions of $20 \mathrm{~mL}$. By means of thin layer chromatography, the chemical profile was performed and sixteen new groups were formed according to its chemical profile. It was recovered $3.04 \mathrm{~g}$ (yield $81 \%$ ). It was noticed that more polar substances were eluted after the fraction 94. After the fraction 124, all material eluted was recovered in a unique fraction (F16), as showed at Figure 2.

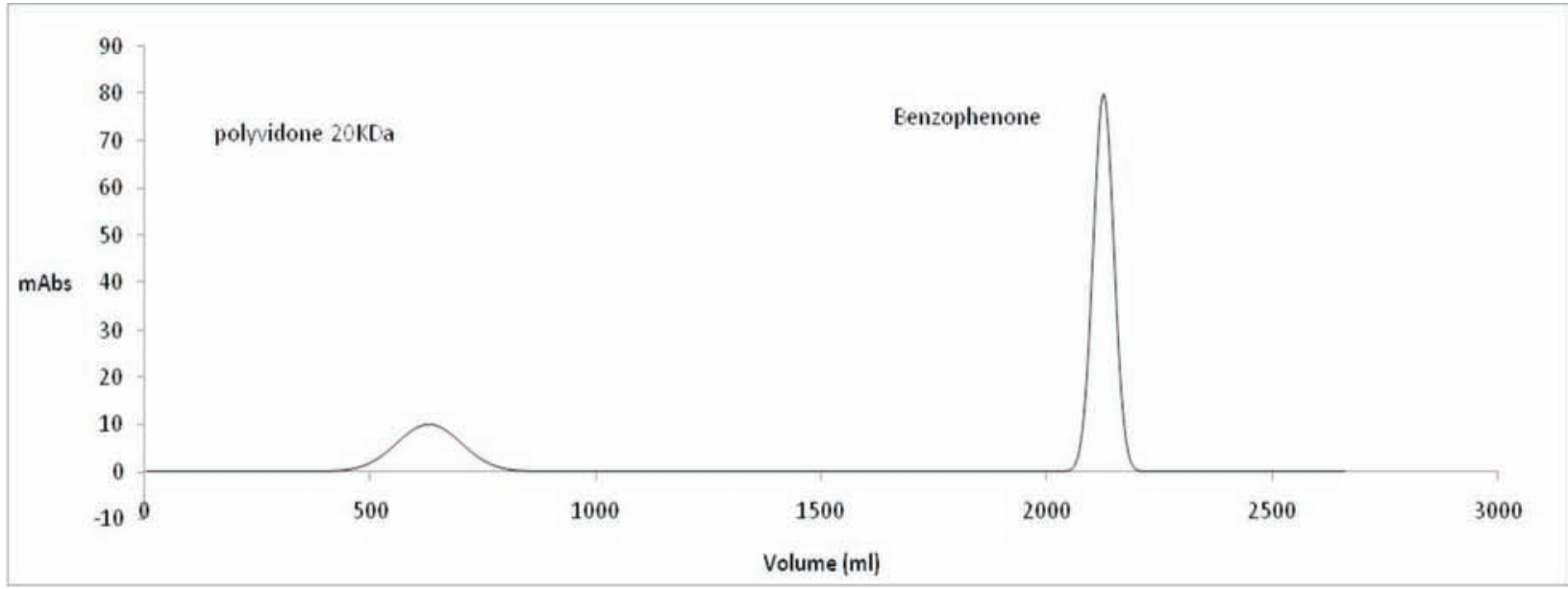

Figure 1. Gel permeation chromatogram (Sephadex ${ }^{\mathrm{TM}}$ LH-20 gel) to perform the dynamic behavior of the chromatographic system. The first peak refers to the total exclusion volume (polyvidone $20 \mathrm{kDa}$ ) and the second refers to the total inclusion volume (benzophenone). The region between them is the selective permeation region. Data collected at $254 \mathrm{~nm}$. Ethanol as mobile phase at 5 $\mathrm{mL} \cdot \mathrm{min}^{-1}$ and column with $50 \mathrm{~mm}$ diameter X $1210 \mathrm{~mm}$ length.

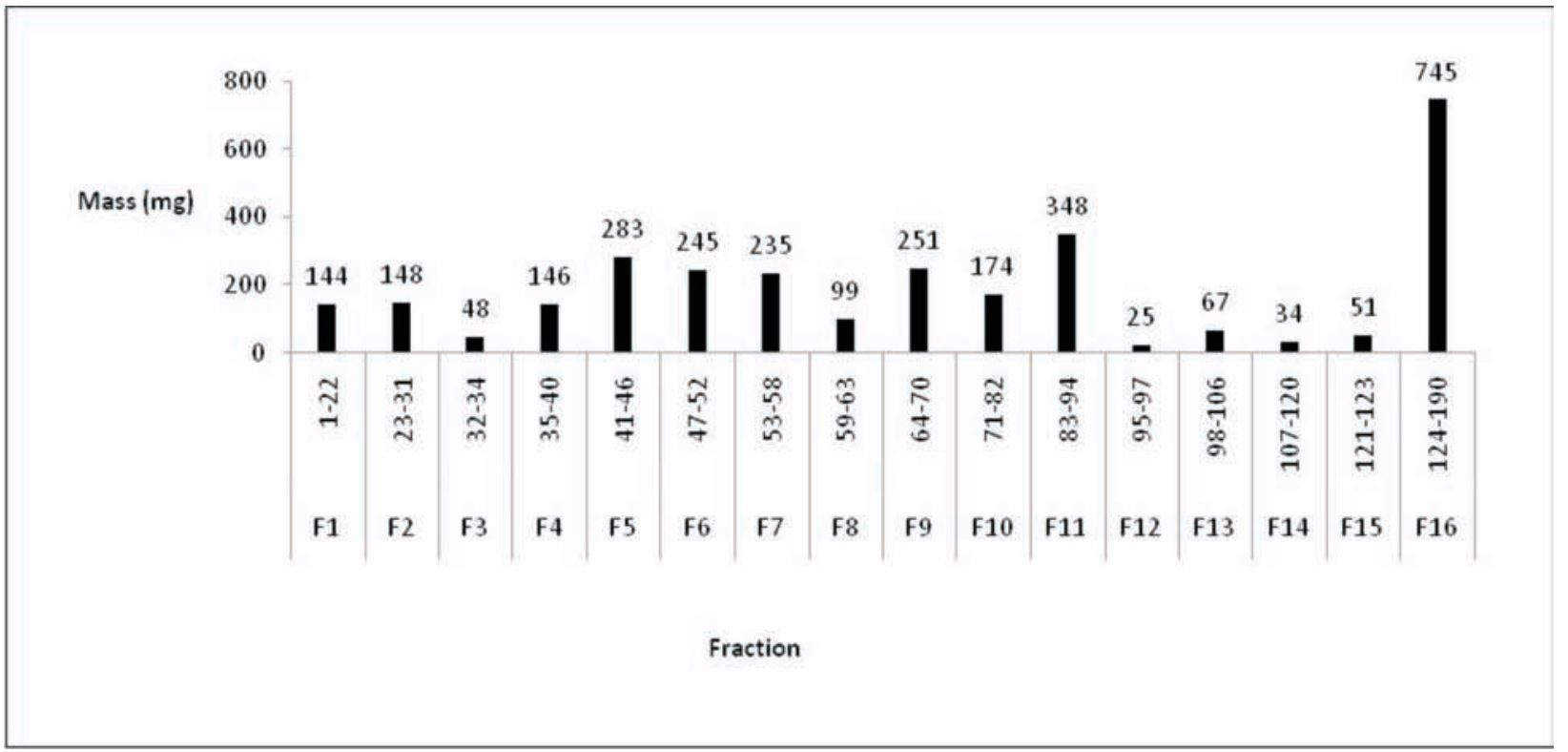

Figure 2. Mass distribution profile of the samples after grouping. The black bars refer to the mass obtained after grouping. The numbers below the bars refer to the number of the tubes in the fractionating procedure to obtain the respective $\mathrm{F}$ fraction. 


\section{Results of leishmanicidal assay}

It was verified that the fractions F2, F3, F4, F7, F9, F11, F12 and F13 were the more active, showing inhibition of the growing against amastigota of Leishmania (L.) amazonensis (in vitro assay) higher than $80 \%$ at 200 $\mu \mathrm{g} . \mathrm{mL}^{-1}$. The crude extract and the fractions F8 and F16 showed proliferative effect. As showed in Figure 3.

Concentration that inhibits $50 \%$ of the growing (IC50) was performed in vitro assays for the more active fractions against amastigota cell of Leishmania (L.) amazonensis. These values were obtained by means of nonlinear regression from data obtained at $100 \mu \mathrm{g} \cdot \mathrm{mL}^{-1}$ to $0.2 \mu \mathrm{g} . \mathrm{mL}^{-1}$ by means of successive dilutions. The results are presented in Table 1.

Impact of crude extracts and fractions on the viability of Leishmania (L.) amazonensis and on the proliferation of human PBMC

The crude extracts and fractions were evaluated about their antileishmania potential and their cytotoxity activity against normal cells using the PBMC proliferation PHA-induced assay. The results on the Table 2 show that the fractions F2, F3, F4, F7, F9, F11, F12 and F13 were the more active against amastigota of Leishmania (L.) amazonensis. Only the F11 and F12 fractions did not show a significant inhibitory effect on PBMC proliferation when compared with control (DMSO, 0.01\%).

\section{DISCUSSION}

Several studies has been carried out using natural products as a source to obtain species that can be used as a target in treatment of leishmaniasis (Rao et al., 2004; Ayres et al., 2007; Dube et al., 2007), mainly from vegetal source (Rocha et al., 2005; Muzitano et al., 2006; Braga et al., 2007; Brenzan et al., 2007; Soares et al., 2007). These studies look at to increase the therapeutic arsenal, because there is a lack of effective and safety medicines. The botany family Myrtaceae has a broad dispersion. It has 133 genera and about 3800 species (Wilson et al., 2001). Several studies present the results about isolation and biological activities of substances from Myrtaceae, as example the cytotoxic actions against tumoral cells (Balunas et al., 2006; Werka et al., 2007), anti-inflammatory action (Lima et al., 2007; Jiang \& Xu, 2003), antioxidant action (Marzouk et al., 2007), bactericidal (Schmidt et al., 2006) and fungicidal (Woollard et al., 2008) activities. Thus, species from this family has been important targets to isolation of actives substances and developing of new drugs. Blepharocalyx salicifolius (Kunth) O. Berg, Myrtaceae, popularly knew as guamirim, cambuim, murta, is a exemplar of Myrtaceae family. There are few studies about biological activity of Blepharocalyx salicifolius. Limberger et al. (2001) has studied the biological effects of the leaves infusions as bactericidal agent, anti-inflammatory, antinociceptive and antispasmodic. The results showed a great bactericidal effects against $S$. aureus and $E$. coli species and fresh leaves had antispasmodic effects.

Table 1. IC50 of the more active fractions. Results in $\mu \mathrm{g} . \mathrm{mL}^{-1}$ obtained by means of nonlinear regression from curve obtained by experiments to verify the activity of the extract from 200 $\mu \mathrm{g} \cdot \mathrm{mL}^{-1}$ to $3.125 \mu \mathrm{g} \cdot \mathrm{mL}^{-1}$.

\begin{tabular}{ccc}
\hline Fractions & Concentration $\left(\mu \mathrm{g} . \mathrm{mL}^{-1}\right)$ & $\mathrm{R}^{2}$ fit $\mathrm{R} \mathrm{R}^{2}$ \\
\hline F2 & 28.8 & 0.93 \\
F3 & 28.1 & 0.99 \\
F4 & 23.6 & 0.98 \\
F7 & 25.8 & 0.90 \\
F9 & 20.0 & 0.80 \\
F11 & 27.5 & 0.96 \\
F12 & 22.7 & 0.99 \\
F13 & 19.2 & 0.98 \\
\hline
\end{tabular}

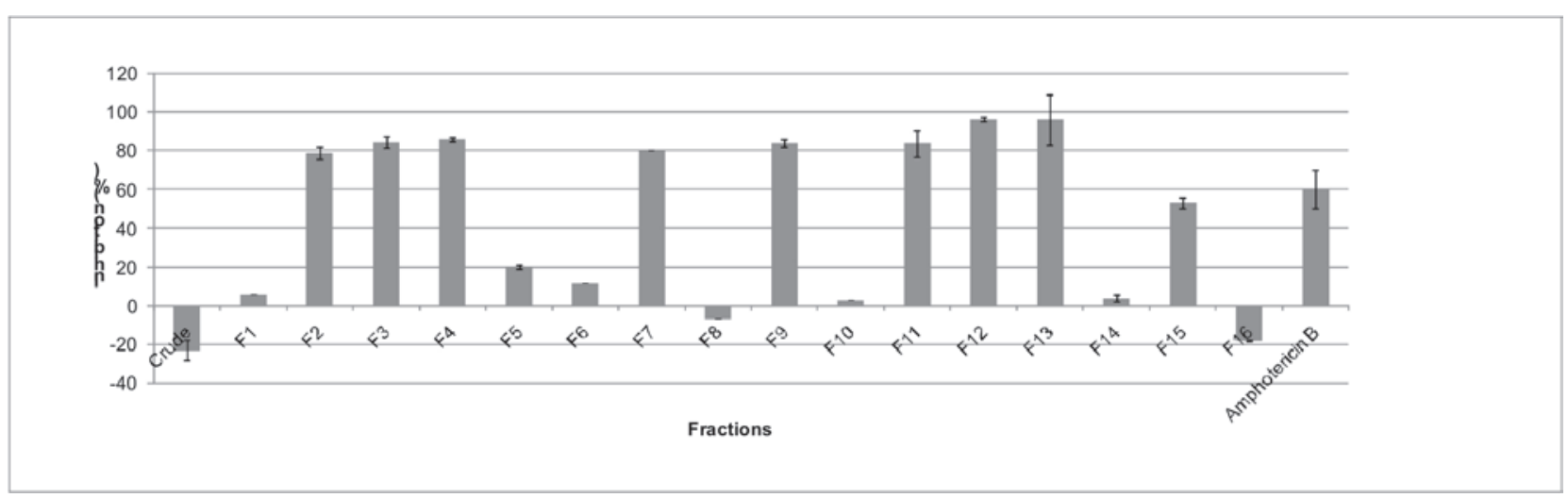

Figure 3. Results of the experiments with amastigota Leishmania (L.) amazonensis cells showing the growth inhibition percentage for each fraction at $20 \mu \mathrm{g} . \mathrm{mL}^{-1}$. The crude, F8 and F16 extracts were growth stimulant (negative results) whereas the others fractions, specially F2, F3, F4, F7, F9, F11, F12 and F13 were deleterious to the Leishmania cells (positive results). 
Table 2. Effect of Blepharocalyx salicifolius ethanolic extract and fractions on the growth of Amastigotes of Leishmania (L.) amazonensis and on the proliferation of human peripheral blood mononuclear cells stimulated with PHA.

\begin{tabular}{ccc}
\hline Sample & \% Amastigote inhibition growth & \\
\hline Crude & \%PBMC proliferation & \\
F1 & $-23.0 \pm 5.00$ & $86.80 \pm 11.60$ \\
F2 & $5.73 \pm 0.10$ & $62.50 \pm 14.00$ \\
F3 & $78.70 \pm 3.00$ & $68.70 \pm 18.00^{*}$ \\
F4 & $84.50 \pm 3.00$ & $65.80 \pm 14.00^{*}$ \\
F5 & $86.00 \pm 1.00$ & $60.20 \pm 14.00^{*}$ \\
F6 & $20.00 \pm 1.00$ & $67.30 \pm 26.00$ \\
F7 & $11.32 \pm 0.04$ & $56.10 \pm 15.00$ \\
F8 & $80.00 \pm 2.00$ & $74.00 \pm 15.00^{*}$ \\
F9 & $-6.86 \pm 0.03$ & $60.90 \pm 17.00$ \\
F10 & $84.00 \pm 2.00$ & $56.95 \pm 17.53^{*}$ \\
F11 & $2.70 \pm 0.05$ & $71.60 \pm 15.00$ \\
F12 & $83.60 \pm 7.00$ & $81.50 \pm 12.00$ \\
F13 & $96.00 \pm 1.00$ & $80.30 \pm 14.00$ \\
F14 & $96.00 \pm 13.00$ & $69.80 \pm 11.00$ \\
F15 & $4.00 \pm 2.00$ & $67.70 \pm 5.90$ \\
F16 & $53.00 \pm 3.00$ & $73.50 \pm 16.00$ \\
DMSO & $-17.92 \pm 0.20$ & $63.10 \pm 18.00$ \\
Data are expressed as the mean \pm standard error of threa independent \\
experiments or sixb independent experiments performed in triplicate. * \\
Statistically different of control (DMSO 0.01\%), $p<0.05$. \\
& & $97.00 \pm 2.00$ \\
\hline & $5.00 \pm 7.00$ &
\end{tabular}

Preliminary studies carried out at Laboratory of Chemistry of the Natural Products, Fiocruz, revealed that fractions F11 and F12 from Blepharocalyx salicifolius ethanolic extracts were active against Leishmania (L.) amazonensis amastigotas cells and had low toxicity against mononuclear cells of human peripheral blood.

Despite the fact that the raw extract did not show leishmanicidal activity, it was observed that eight fractions (50\% of the total fractions) were active against Leishmania (L.) amazonensis at range of 19 to $29 \mu \mathrm{g} \cdot \mathrm{mL}^{-1}$.

In the raw extract, the actives compounds could be at minor concentration diluted between hundreds of others compounds besides several compounds can have antagonic biological effects each other. The purification process increase the individual chemical characteristic for each species, thus the fraction seems to be more effective than the raw extract, as example, the fraction F12 had 86\% of inhibition effect and $25 \mathrm{mg}(0,67 \%$ of the total mass $)$ whereas the F16 was not active ( $20 \%$ of the total mass).

The usual drugs used on leihsmaniasis therapy present several adverse effects as nephrotoxicity, hepatotoxicity and low efficacy (Soto et al., 2001). Besides the fractions F11 and F12 present activity against amastigota Leishmania (L.) amazonensis cells, they were not toxic to blood human cells. In the present study, we used cell proliferation of mononuclear cells (lymphocytes and monocytes) to assess the immunotoxic potential of these fractions and the crude extract because these in vitro models are currently used for pre-screening of immunotoxic potential, as a strategy. In this context, if the cells are viable $(80 \%$ or greater) basic functionality can be determined assessing cell proliferation using mitogens such as plant lectin (PHA) especially for T cells (Carfi et al., 2007). Compounds may affect lymphocytes which are the primary effectors and regulators of acquired immunity, essential for anti-parasitic response as observed to leishmania infections. In this disease, the immunity is dependent on $\mathrm{T}$ lymphocytes $\mathrm{CD}^{+}$positive with the Th1 type cytokine profile such as IFN- $\gamma$ that activates the macrophages to kill the parasites (Narayan et al., 2009). Therefore, the low toxicity observed to actives fractions F11 and F12 strongly suggest that Blepharocalyx salicifolius has a great potential to isolation of the actives substances against Leishmaniasis and with low toxicity.

\section{REFERENCES}

Ayres DC, Marcucci MC, Giorgio S 2007. Effects of brazilian propolis on Leishmania amazonensis. Mem Inst Oswaldo Cruz 102: 215-220.

Balunas MJ, Jones WP, Chin YW, Mi Q, Farnsworth NR, Soejarto DD, Cordell GA, Swanson SM, Pezzuto JM, Chai HB, Kinghorn AD 2006. Relationships between inhibitory activity against a cancer cell line panel, profiles of plants collected, and compound classes isolated in an anticancer drug discovery project. Chem Biodiv 3: 897-915.

Braga FG, Bouzada MLM, Fabri RL, Matos MD, Moreira FO, Scio E, Coimbra ES 2007. Antileishmanial and antifungal activity of plants used in traditional medicine in Brazil. $J$ Ethnopharmacol 111: 396-402.

Brenzan MA, Nakamura CV, Dias BP, Ueda NT, Young MCM, Cortez DAG 2007. Antileishmanial activity of crude extract and coumarin from Calophyllum brasiliense leaves against Leishmania amazonensis. Parasitol Res 101: 715-722.

Carfi M, Gennari A, Malerba I, Corsini E, Pallardy M, Pieters R, Van Loveren H, Vohr HW, Hartung T, Gribaldo L 2007. In vitro tests to immunotoxicity: A preliminary study. Toxicology 229: 11-22.

Dube A, Singh N, Saxena A, Lakshmi V 2007. Antileishmanial potential of a marine sponge, Haliclona exigua (Kirkpatrick) against experimental visceral leishmaniasis. Parasitol Res 101: 317-324.

Gazzinelli G, Katz N, Rocha RS, Colley DG 1983. Immune response during human schistosomiasis mansoni $\mathrm{X}$. Production and standartization of an antigen-induced mitogenic activity by peripheral blood mononuclear cells from treated but not active cases of schistosomiasis. $J$ Immunol 130: 2891-2895.

Jiang J, Xu Q 2003. Immunomodulatory activity of the aqueous extract from rhizome of Smilax glabra in the later phase of adjuvant-induced arthritis in rats. $J$ Ethnopharmacol 85: 53-59.

Lima LA, Siani AC, Brito FA, Sampaio ALF, Henriques MGMO, 
Riehl CAS 2007. Correlation of anti-inflammatory activity with phenolic content in the leaves of Syzygium cumini (L.) Skeels (Myrtaceae). Quim Nova 30: 860864.

Limberger RP, Sobral MEG, Zuanazzi JAS, Moreno PRH, Schapoval EES, Henriques AT 2001. Biological activities and essential oil composition of leaves of Blepharocalyx salicifolius. Pharm Biol 39: 308-311.

Marzouk MSA, Moharram FA, Mohamed MA, Gamal-Eldeen AM, Aboutabl EA 2007. Anticancer and antioxidant tannins from Pimenta dioica leaves. J Bioscience 62: 526-536.

Muzitano MF, Tinoco LW, Guette C, Kaiser CR, Rossi BB, Costa SS 2006. Assessment of antileishmanial activity of new and unusual flavonoids from Kalanchoe pinnata. Phytochemistry 67: 2071-2077.

Narayan S, Bimal S, Singh SK, Grupta AK, Singh VP, Sinha PK, Das P 2009. Leishmania donovani vs immunity: T-cells sensitized from Leishmania of one donor may modulate their cytokines pattern on re-stimulation with Leishmania from different donor in visceral leishmaniasis. Exp Parasitol 121: 69-75.

Pecoul B, Chirac P, Trouiller P, Pinel J 1999. Access to essential drugs in poor countries-A lost battle? Jama-J Am Med Assoc 281: 361-367.

Rao KV, Kasanah N, Wahyuono SU, Tekwani BL, Schinazi RF, Hamann MT 2004. Three new manzamine alkaloids from a common Indonesian sponge and their activity against infectious and tropical parasitic diseases. J Nat Prod 67: 1314-1318.

Rocha LG, Almeida J, Macedo RO, Barbosa-Filho JM 2005. A review of natural products with antileishmanial activity. Phytomedicine 12: 514-535.

Schmidt JM, Noletto JA, Vogler B, Setzer WN 2006. Abaco Bush medicine: chemical composition of the essential oils of four aromatic medicinal plants from Abaco Island, Bahamas. J Herbs Spices Med Plants 12: 43-65.

Soares DC, Pereira CG, Meireles MAA, Saraiva EM 2007. Leishmanicidal activity of a supercritical fluid fraction obtained from Tabernaemontana catharinensis. Parasitol Int 56: 135-139.

Soto J, Toledo J, Gutierrez P, Nicholls RS, Padilla J, Engel J, Fischer C, Voss A, Berman J 2001. Treatment of american cutaneous leishmaniasis with miltefosine, an oral agent. Clin Infect Dis 33: 57-61.

Teixeira MCA, Santos RJ, Sampaio RB, Carvalho LP, Santos WLC 2002. A simple and reproducible method to obtain large numbers of axenic amastigotes of different Leishmania species. Parasitol Res 88: 963-968.

Werka JS, Boehme AK, Setzer WN 2007. Biological activities of essential oils from Monteverde, Costa Rica. Nat Prod Commun 2: 1215-1219.

Wilson PG, O'Brien MM, Gadek PA, Quinn CJ 2001. Myrtaceae revisited: A reassessment of infrafamilia groups 1. Am J Bot 88: 2013-2025.

Woollard JMR, Perry NB, Weavers RT, Klink JW 2008.
Bullatenone, 1,3-dione and sesquiterpene chemotypes of Lophomyrtus species. Phytochemistry 69: 1313-1338.

WHO (World Healt Organization) 2003. Public health mapping group communicable diseases (CDS). http://www.who. int/leishmaniasis/leishmaniasis_maps/en/index.html, access at October 2003. 